\title{
Katharina Nieswandt \\ Authority and Interest in the Theory of Right
}

\begin{abstract}
I suggest a new role for authority and interest in the theory of right: Rights can be explicated as sets of prohibitions, permissions and commands, and they must be justified by interests.

I argue as follows: (1) The two dominant theories of right— "Will Theory" and "Interest Theory"- - have certain standard problems. (2) These problems are systematic: Will Theory's criterion of the ability to enforce a duty is either false or empty outside of its original legal context, whereas Interest Theory includes in the definition of a right what actually belongs to the justification of the practice within which that right is assigned. (3) I recast the connection between authority, interests and rights in a way that avoids each theory's standard problem. (4) The resulting theory also has three further advantages: It analyzes rights in terms of very basic and familiar concepts; it mirrors the understanding of rights in actual public discourse, and it is compatible with a wide selection of moral theories. Since its core is about a specific use of modal auxiliary verbs, I call this new theory the "Modal Theory of Right."
\end{abstract}

Key Words

Will Theory $\bullet$ Interest Theory $\bullet$ G.E.M. Anscombe $\bullet$ Deontic Modals

\section{Acknowledgements}

I am deeply grateful to the many colleagues who commented on earlier drafts: Thomas Breed, Michael Goodhart, Steven Engstrom, Michael Kessler, Oded Na'aman, Josiah Ober, Japa Pallikkathayil, Michael Thompson, Kevin Toh, Grégoire Webber, and particularly to Ulf Hlobil. Your advice and questions were invaluable. I furthermore thank the Andrew W. Mellon Foundation for funding my research during this time.

Final Draft, December 2016 


\section{Introduction: A Tale of Two Incompatible Theo- ries and a Counterproposal}

There currently are two dominant theories of right, the Will Theory and the Interest Theory. Both theories have long-known problems and both are commonly regarded as incompatible with the other. ${ }^{1}$ According to Will Theory, to possess a right is to be able to enforce or waive some duty on the part of another person. ${ }^{2}$ Thus, Will Theory's main claim says:

(W) $X$ possesses a right $R$ iff $X$ is able to enforce (or waive) a duty of another person, where this duty is correlative to $R$.

Section 4 discusses what it would mean to "be able to enforce (or waive) a duty of another person," but at the current stage our formulation of $W$ must be vague enough so as to include a number of different interpretations of Will Theory.

Will Theory's main historical root is Kant's "Doctrine of Right." Kant regards freedom from the interference of others as a prerequisite of human agency. He infers from this a right to this freedom, which we cannot deny to anyone without contradicting ourselves. All other rights, Kant argues, are justified restrictions of this freedom right, and their justification lies in the protection of the freedom rights of other people. ${ }^{3}$ Some contemporary Will Theorists take this idea one step further. They argue that human agency requires a whole set of basic rights. ${ }^{4}$ One attraction of the Kantian framework is that it promises to give a non-normative and hence less contested justification for something that is normative and is highly contested: Mere metaphysical considerations about agency are supposed to justify a substantial catalogue of basic rights. One problem with Will Theory's main claim, $W$, however, is its implication that people who are unable to enforce any duties (such as comatose patients or babies) are unable to possess any rights.

According to the competing Interest Theory, to possess a right is to possess an interest that puts another person under some duty. ${ }^{5}$ Thus, Interest Theory's main claim says:

$\mathrm{X}$ possesses a right $\mathrm{R}$ iff $\mathrm{X}$ has an interest that grounds a duty of another person.

Sections 6-8 discuss what it would mean for someone's interest to "ground a duty of another person," but at the current stage $I$, too, must remain sufficiently vague.

Interest Theory starts from the plausible idea that rights serve a function and that rights usually benefit the right-holder. Bentham is often cited as the first proponent of this idea, ${ }^{6}$ but there are virtue ethicist versions, too. ${ }^{7}$ One attraction of Interest Theory is that it grants rights to everyone who has interests, which certainly includes 
comatose patients and babies and which could easily be extended to animals, too. One problem with Interest Theory's main claim, $I$, however, is its implication that we are unable to possess rights which exclusively or mainly protect the interests of others. (An example is the right to governmental child support, which is a right of parents, but intended to protect the interest of their children). ${ }^{8}$ Most Will and most Interest Theorists see their theory as incompatible with the other; "the debates between them are often intense [...][and] seemingly interminable."

Against this standoff, I offer the following proposal: (1) Will and Interest Theory are falsely seen as complete (and hence incompatible) theories of right. We need Will Theory's key concept of authority, in order to specify what it is to possess a right, while we must appeal to interests, in order to justify rights. (2) Will Theory's misconception of the role of authority and Interest Theory's misconception of the role of interest both result from a failure to distinguish three questions: What prohibitions, commands and permissions does a given right authorize?, What interests does this right protect? and: Who possesses this right? In other words, both Will and Interest Theory fail to distinguish between the definition of rights, their justification and their possession.

(3) Once we make these distinctions, we can redefine the roles of authority and interest in a way that avoids Will and Interest Theory's standard problems. I shall call the resulting theory the Modal Theory of Right, since the proper understanding of authority and interest will turn out to be through understanding a specific use of modal auxiliary verbs.

I proceed as follows: Section 2 argues that the most recent and refined attempt to show the incompatibility of Will and Interest Theory fails. Section 3 distinguishes three questions that any complete theory of right would have to answer: the abovementioned questions of the definition, the justification and the possession of rights. Section 4 then discusses Will Theory. I show that Will Theory's standard problem is larger than commonly discussed and that it stems from a missing explanation of how rights authorize. I suggest such an explanation, which I summarize as the first claim of Modal Theory, M1 (Section 5). The suggested understanding of the relation between authority and rights avoids Will Theory's standard problem, and it answers the definition question. Section 6 then turns to Interest Theory. I suggest an alternative understanding of the relation between interests and rights, which I summarize as the second claim of Modal Theory, M2. M2 answers the justification question. I then show that $M 2$ avoids Interest Theory's standard problem, and that it captures the actual role of interest in debates about rights, while Interest Theory misconstrues this role (Section 8). As a last step, Section 9 addresses the question of possession, the answer to which is $M 3$, the third and last claim of Modal Theory. Section 10 summarizes my results.

This paper starts from the premise that authority and interest are key elements of any correct theory of right. My argument hence is conditional: If authority and 
interest are to play a central role in the theory of right, it will be the one described below.

\section{Excursus: Will and Interest Theory Have Not Been Shown to Be Incompatible}

Neophytes to the debate might be surprised to learn that Will and Interest Theory are commonly regarded as incompatible: Don't they stress different aspects of rights, rather than contradict each other? Couldn't we hold, for example, that to possess a property right in one's savings is (among other things) to be able to enforce a bank clerk's duty to pay out the respective amount and at the same time hold that the bank clerk's duty is grounded in one's interest? In other words, is it not plausible to assume that rights are characterized by both, the authority they confer over other people's behavior and the fact that this authority protects an interest? This understanding does indeed come close to the view I shall offer below. The current section is intended to alleviate principled worries regarding the very idea of such a hybrid theory. Readers who are unfamiliar with the history of the debate might want to skip this meta-dialectical excursus and proceed to Section 3

Previous hybrid proposals (such as Gopal Sreenivasan's) ${ }^{10}$ have been criticized by both Will and Interest Theorists. ${ }^{11}$ This criticism, however, has not established that Will and Interest Theory's key ideas are indeed incompatible. The most developed and probably best-known principled objection to hybrid theories of right is by the Interest Theorist Matthew Kramer. Kramer argues that the incompatibility of Will and Interest Theory is readily apparent from the following formulations of the two theories: A Will Theorist considers it "necessary and sufficient" that a right-holder, $X$, be "competent and authorized to demand/waive the enforcement of the duty that is correlative to the right." By contrast, an Interest Theorist considers this "neither necessary nor sufficient," while fulfillment of a second criterion is "necessary," viz. that the duty correlative to the right "normatively protects some aspect of X's situation that on balance is typically beneficial for a being like $X .{ }^{\prime \prime 2}$ In short, Kramer argues that Will Theory's claim that a certain condition is "necessary and sufficient" is incompatible with the claim that there is a further necessary condition - specified by Interest Theory. ${ }^{13}$ But this inference is invalid: If a first criterion, $C_{W}$, is sufficient for $X$ to have a right, this does not logically exclude that a second criterion, $C_{I}$, is necessary for $X$ to have a right, since $C_{W}$ and $C_{I}$ might not be independent of each other. For the two criteria in question such a dependency is indeed not just possible, but highly plausible: One of the main claims of the theory I suggest below is that the relevant type of authority (demanded by $C_{W}$ ) only exists where the relevant type of interest does (demanded by $C_{I}$ ). (See section 6 for this.) 
In addition to this, nothing about the two criteria themselves suggests that either of them is sufficient. In the case of our property example, we could consider it necessary for the customer to be "competent and authorized" to demand payment and consider it necessary for this payment to be in her interest, in order for the customer to have a right to the payment. Prima facie, there is no problem with the assumption that the two criteria are compatible, while none of them alone suffices.

The most developed principled argument for "the untenability of a sophisticated hybrid theory of rights" ${ }^{14}$ hence depends on two implausible assumptions: first, that the relevant kind of authority, demanded by the Will-Theoretic criterion, does not derive from facts about the right-holder's interests; second, that this criterion must be understood as a sufficient condition. There hence seem to be no principled objections against the project of a hybrid theory.

\section{Three Questions for a Theory of Right}

In the introduction, I distinguished three questions, which we can ask with respect to any given right $R$ :

(Definition) What prohibitions, commands and permissions does $R$ authorize?

(Justification) What interests does $R$ protect?

(Possession) Who possesses R?

The debate so far, I believe, suffers from a failure to distinguish these three questions. A recast version of Will Theory, I suggest, would answer the definition question. A recast version of Interest Theory would answer the justification question. And once these two questions are answered, the possession question becomes a simple empirical question.

Recently, Will and Interest Theory are often understood as attempts to answer the possession question. Following Wenar, ${ }^{15}$ this interpretative shift is a reaction to their decade-long standoff: We might be able to explain what rights are, by explaining their Hohfeldian logical correlative, duties. ${ }^{16}$ Right-based duties, some believe, differ from other duties - e.g. duties of benevolence-in that they are directed at (i.e. owed to) the possessor of the right. ${ }^{17}$ (The bank clerk's duty to pay the money, e.g., is directed at me.) The hope is that an explication of 'directed duty' could then serve to explicate the concept 'right'. On this understanding, Hohfeld has given us an analysis of rights through duties, but has failed to separate right-based duties from other duties, such as a duties of benevolence. 
I doubt whether the distinction of right-based versus other duties does indeed line up with the distinction of directed versus non-directed duties. ${ }^{18}$ All right-based duties might be directed, but it seems that at least some other duties are directed, too: Isn't, e.g., my duty to offer my seat on the bus to the pregnant passenger now entering owed to that passenger? But unless I happen to sit on a seat reserved for people with special needs, she certainly has no right to my seat.

The interpretation of Will and Interest Theory as different theories of the possession of rights, however, is also problematic for a further reason: If what I shall say below about rights is correct, then it would render both theories superfluous. We simply do not need a theory of the possession of rights anymore if we have a theory of their definition and their justification.

\section{Will Theory's Main Problem: What Means "Can Enforce?"}

The standard accusation against Will Theory says that it denies rights across the board to certain groups of people. Those who are generally unable to enforce any rightssuch as patients in a coma or babies_cannot have any rights within Will Theory. This accusation, I shall argue, points to a consequence of Will Theory's basic problem rather than its root. Will Theory's basic problem runs much deeper: Any possible interpretation that we can give of the concept 'ability to enforce' in a moral context is either false (in that it denies rights to people who seem to have them) or is empty.

Modern Will Theory started as a descriptive account of the role of rights within Anglo-Saxon law. ${ }^{19}$ In other words, its original aim was to analyze the form and function of legal rights (within one particular legal system). Inspired by Kant, Hart famously characterized legal rights as restrictions on the freedom of others, which the rightholder may enforce. It is the holder of such a legal right "who is a small scale sovereign" for Hart. ${ }^{20}$ In this legal context, to enforce simply means to sue, should the other party not willfully heed to your demand. ${ }^{21}$

Contemporary Will Theory has extended its domain of application: Will Theory now is a theory of rights in general: moral rights, legal rights and more-some current discussions of rights even include the "rights" of players in games. ${ }^{22}$ Where moral rights are concerned, Will Theory has furthermore become a normative theory: The right-holder is morally entitled to restrict the choices of others, and these others wrong the right-holder if they don't comply. At the same time, Will Theory has kept Hart's characterization of the right-holder as sovereign and of rights as demands against others which the right-holder is able to enforce. Outside of a legal framework, however, it becomes unclear what it means to be able to enforce such a demand (or to be authorized and competent to do so, as Kramer puts it). In the legal case, an official system 
of rules is in place, as are institutions that watch over these rules, change them, promulgate them, punish transgressions, settle disagreements about the rules etc. Within such a rule-governed practice with permanent social institutions, "enforcement" has a clear meaning: The holder of a legal right is able to enforce that legal right in the sense that she has standing to sue. Should she be unable to do so (e.g. because of a cognitive deficiency) some proxy will have standing on her behalf. In some situations, she (or the proxy) might decide to waive the right, or it might turn out that the legal institutions are malfunctioning, so that she cannot obtain due process. What it means for her to have the respective right, however, is very clear, even in such cases: There is a legal procedure that can be initiated-an institutional machinery that can be turned on, so to speak — with the aim of extorting what the right-holder has been denied.

One important respect in which moral rights differ from legal rights is that such an official system of rules and social institutions is lacking in the moral case. Without such a system, however, it becomes unclear what it means to say that $X$ is able to enforce against $Y$ the demands that her right $R$ entails. There is no similar set of rules and, more importantly, no machinery in place that $X$ could use against $Y$. As far as $I$ can see, enforcement could mean either of three things in the moral case: (1) $X$ is justified (by the rules of the respective moral practice?) in demanding that $Y$ respect the demands which $R$ entails and she is able to force $Y$ to respect the demands which $R$ entails. (2) $X$ is justified in demanding that $Y$ respect the demands which $R$ entails and she is able to demand that $Y$ respect the demands which $R$ entails. (3) $X$ is justified in demanding that $Y$ respect the demands which $R$ entails.

None of these three interpretations, though, yields a result that is both plausible and interesting: The third interpretation is empty, while the other two also expropriate healthy adults of most of their (apparent) rights. To demonstrate this, let me spell out the result of each interpretation for two exemplary cases: Case 1 are the much discussed comatose and babies. For the second case, imagine the following scenario: $X$ leaves the room in the public library and another person, $Y$, takes her unattended laptop computer. Assume furthermore that $X$ indeed has a moral and not just a legal right to this computer. Case 2 thus is a scenario where $X$ possesses a right, but is unable to defend this right because she is not present to do so. Table 1 lists the results for the two scenarios under each of our three interpretations: 
Table 1: Outcome (right/no right) for two scenarios on three interpretations of Will Theory.

\begin{tabular}{|c|c|c|c|c|}
\hline & & Interpretation 1 & Interpretation 2 & Interpretation 3 \\
\hline & & \multicolumn{3}{|c|}{$X$ is "able to enforce" her right $R$ against $Y$ if ... } \\
\hline & & $\begin{array}{l}\ldots X \text { is justified in demand- } \\
\text { ing that } Y \text { respect the de- } \\
\text { mands which } R \text { entails } \\
\text { and } X \text { is able to force } Y \text { to } \\
\text { respect the demands } \\
\text { which } R \text { entails. }\end{array}$ & $\begin{array}{l}\ldots X \text { is justified in de- } \\
\text { manding this and } X \text { is } \\
\text { able to demand this. }\end{array}$ & $\begin{array}{l}\ldots X \text { is justified in de- } \\
\text { manding this. }\end{array}$ \\
\hline Case 1 & $\begin{array}{l}X \text { is comatose } \\
\text { or a baby. }\end{array}$ & - & - & $\sqrt{ }$ \\
\hline Case 2 & $\begin{array}{l}X \text { is a healthy, } \\
\text { absent adult. }\end{array}$ & - & - & $\sqrt{ }$ \\
\hline
\end{tabular}


Let's look at each of the three columns of Table 1 in turn.

Column 1 says that any demand of yours can only count as a right if you are in a position to force others to respect it. This assigns no rights to those in row 1 , since they are unable to force anyone to do anything. But equally unable is the healthy adult from row 2, who, given her absence, cannot force $Y$ to respect her (supposed) right in the computer. She, too, has no right on this interpretation. But few would assume that our property rights cease as soon as we leave the room; so this first interpretation seems implausible.

Notice two things about the first interpretation before we proceed: (1) The problem that absent healthy adults lose their property rights cannot be solved by interposing a proxy — say, the police or 'the state'. For this proxy incurs the same problem as $X$ herself; that is, it will not always be able to force $Y$ to respect the demands which X's right entails. (The police, for instance, might never catch Y.) (2) Notice also that $X$ would not have a right either if she were present but less powerful than the thief. The first interpretation, in fact, turns all rights into 'rights of the strongest'.

Column 2, like the previous column, awards no rights to comatose and babies, as both are unable to demand anything. What about the absent adult from row 2? Given her absence, she, too, is unable to demand that the other respect those demands which her property right in the computer entails (such as: not to take this item without her permission). Hence, she, too, has no right on the second interpretation, and hence this second interpretation is as implausible as the first. (Notice that a proxy-solution would fail for the same reason as before: The proxy will not always be able to demand of $Y$ that $Y$ respect the demands which $X$ 's right entails.)

At his point, Will Theorists might object by saying that I misunderstand what "being able to" means in our context. A Will Theorist might say: "Healthy adult X is currently not in a position to demand that $Y$ leave her computer alone, because of certain accidental circumstances- $X$ happens to have left the room. But if $X$ returned the next moment, she would be able to demand this. The inabilities of those in row 2 are accidental, while the inabilities of those in row 1 are inabilities in principle; hence it seems unfair to assign the same negative outcome to both. For while Will Theory admittedly has a problem with comatose and babies, the suggested problem with the absent adult could easily be solved if we added 'in principle' to the interpretation listed in column 2." Following this reply, column 2 would be modified so as to read: " $X$ is justified in demanding this and $X$ is, in principle, able to demand this." Presupposing that our Will Theorist can spell out a suitable notion of "in principle," this modification would indeed allow absent adults to keep their property rights. Nevertheless, this modification is not an option as it would make the well-known problem from row 1 unsolvable: Prior to our modification, the claim that babies and comatose adults cannot have any rights was just an unwelcome consequence of Will Theory, which its proponents could still hope to circumvent in the future. But once we define rightholders as those who are in principle able to demand what their right entails, we rule out 
rights for babies and comatose adults by definition. Thus, the suggested modification only worsens Will Theory's situation. ${ }^{23}$ Our Will Theorist might react to this by altering her proposal as follows: 'Let's keep the supplement 'in principle,' but give it a different reading. Instead of saying that the comatose and the baby's inability constitute inabilities in principle and that this is what distinguishes their inability from that of the healthy adult, let's treat both groups alike, as originally suggested, and say that they all are 'in principle able, though currently unable' to demand what $R$ entails: the healthy adult could demand this if she were to step into the room, the comatose if she were to awake from her coma, the baby, had she already grown up." This second modification would indeed give us the desired result; that is, those in both rows could now possess rights. ${ }^{24}$ Effectively, however, this modification collapses column 2 into column 3. For what could the resulting claim that $X$ has a right if " $X$ is justified in demanding this and $X$ is in principle able to demand this" mean, on our new understanding of "in principle," except that the respective person would be justified in demanding what $R$ entails, were she ever factually able to demand this? In other words, what would it say more than that she would be justified in demanding this? The latter, however, is precisely the interpretation given in column 3-and as the following considerations will show, it is not a tenable interpretation of Will Theory either.

Column 3 , in giving a less fastidious criterion, avoids all previous difficulties. Here, someone has a right if she would be justified in making a particular sort of demand. Whether she is able to make this demand (as column 2 required) or whether she is able to force others to obey her demand (as column 1 required), any such empirical fact is irrelevant for the question of whether or not she would be justified in making it. In other words, on the third interpretation, someone's abilities are irrelevant for whether or not she has a right. What result does this claim yield for our two rows? Since inability does not matter, the fact that those in row 1 are in principle unable to make demands does not matter; that is, the third interpretation finally allows us to assign rights to comatose and babies. And since inability does not matter, the fact that the absent adult of row 2 is currently unable to make a demand does not matter; that is, the third interpretation finally allows us to assign her a property right in the computer. Thus, the third interpretation gives the desired result for both test cases and hence seems highly plausible.

The third interpretation, however, deprives Will Theory of all characteristic content. For if we think that "to be justified in demanding" has nothing to do with an ability to demand (neither with a cognitive ability, nor with a suitable occasion, nor with actual power), then to say: " $X$ has a right $R$ against $Y$ if $X$ is justified in demanding that $Y$ respect the demands which $R$ entails" simply is to say: " $X$ has a right $R$ against $Y$ if $Y$ is under a duty to respect the demands to which $R$ entitles $X$." $X$ has a right against $Y$ if $X$ is justified in demanding of $Y$, and for $X$ to be justified in demanding of $Y$ is for $Y$ to be under a duty to do as demanded by $X$. On the third interpretation, $X$ thus has a right $R$ against $Y$ if $Y$ is under a correlative duty toward $X$. This means, however, that 
the third interpretation collapses Will Theory into the thin conceptual analysis of the primary meaning of right given by Wesley Newcombe Hohfeld. ${ }^{25}$ Hohfeld's analysis is almost universally accepted. Most importantly, it is accepted by Will and Interest Theorists alike. Therefore, if Will Theory does not go beyond Hohfeld's analysis on any point, it ceases to be an independent theory of right at all. Everything that was characteristic of Will Theory — that the right-holder is comparable to a "sovereign," who rules over others (albeit in a very limited domain)—has been removed. The third interpretation reduces Will Theory to a definition that its main competitor as well as other, lesser-known alternatives willingly accept — that they, in fact, already contain.

Our result regarding Will Theory's criterion therefore is that, on any non-trivial reading (columns 1 and 2 of Table 1), Will Theory denies most people many of the rights that we take them to have. The commonly discussed cases are just a tiny selection of all the counterexamples which Will Theory actually incurs, and new counterexamples can be generated systematically by imagining situations in which people are currently unable to defend their rights.

\section{An Alternative Role for Authority: Claim 1 of the "Modal Theory of Right"}

Despite Will Theory's problems, there is something to be said for the claim that what characterizes rights is that rights create a special kind of authority. Rights indeed authorize certain prohibitions, commands and permissions. Thus, one true description of what it is for $X$ to possess a right is that $X$ enjoys certain permissions, while others are under certain demands-demands that can be expressed as prohibitions and commands like the following: "You can't take that-it's $X$ 's" ( $X$ has a property right); "He must do so- - he assured $X$ that he would" ( $X$ has a right as promisee); "You can't use that-you'll hurt somebody" (people in general, including $X$, have a right not to be harmed); "You will do such-and-such—and that's an order!", said by $X$ herself ( $X$, as superior officer, has a right to be obeyed); and so forth ...

Elizabeth Anscombe regarded the semantics of such prohibitions and commands as the key to an analysis of what rights are. She called them "stopping modals" and "forcing modals," after the modal auxiliary verbs that such expressions contain. ${ }^{26}$ Anscombe did not coin a name for the third type of relevant modal claim here, viz. those phrases by which we express the permissions for the holder of the right. Following Roger Teichmann, I shall call these "permitting modals." 27 The first part of my solution builds on Anscombe's idea that an analysis of rights must proceed through an analysis of the use of such deontic modals. The example of property rights might serve to illustrate that idea: For $X$ to have a property right in a certain computer means: (1) No one may take it without her permission (probibition or "stopping modal"); (2) if someone destroys it, this person must compensate $X$ (command/forcing modal), while 
(3) $X$ herself can destroy the computer if she feels like it (permission/permitting modal); (4) she may sell it to others (permission/permitting modal); and so forth. If $X$ has a right, then certain prohibitions and commands apply for others, while certain permissions apply for her. Imagine we were to explain the very idea of property rights to a traveler, in whose culture private property did not exist. We could do so by giving her a list of prohibitions, commands and permissions_or: stopping, forcing and permitting modalsjust like the ones mentioned: 'See, if this is my 'property,' it means that (1) no one can take it unless they've asked me, that (2) others must compensate me, if they break it, that (3) I may make changes to it as I like, while they ..." A complete such list would be a complete specification of what my right consists in; in other words, it would be an explication (of this particular type) of property right. ${ }^{28}$ It would thereby answer our first question for any theory of right, the question of definition. The first claim of the new theory of right that I want to suggest here can hence be put as follows: ${ }^{29}$

(M1) Any right $\mathrm{R}$ can be defined through a set of stopping and forcing modals.

By first sight, one might think that $M 1$, just like the third reading of Will Theory on p. 10 above, does not go beyond Hohfeld's analysis of rights through duties either. This objection is unwarranted, for the following three reasons: (1) Hohfeld's analysis explicates the concept 'right' through its "invariable correlative," 'duty', ${ }^{30}$ whereas M1 explicates 'right' through the special usage of an independent class of expressions, modal auxiliary verbs. Hence, in $M 1$, explicans and explicandum are independent of each other, whereas Hohfeld elucidates the relation $X$ has a right against $Y$ through the converse relation $Y$ has a duty against $X$. (2) The explicans in $M 1$ elucidates through something that is much more basic than the explicandum. After all, modal auxiliary verbs are among the vocabulary that we learn when we first acquire language: We are told as toddlers that we "must" do certain things, "can't" do others, "may" or "may not" do this-and-that; that is, we learn such concepts long before we can be introduced to such demanding concepts as 'a right' or 'a duty'. To define rights through modal auxiliary verbs hence is to define rights through something very simple and fundamental in comparison. (3) The explicans elucidates through something that is not specific to the explicandum, something with which we are familiar from many other contexts (and on which we hence have a much firmer grip). For the normative use of modal auxiliary verbs is in no way limited to rights-contexts: People cannot take what belongs to another (property right), and they need to feed their offspring (right to life). But philosophers cannot infer that such-and-such if doing so would be to affirm the consequent (requirement of theoretical rationality), and chess players need to move the king when he's in check (rule of a game); an applicant cannot be late for her interview if she intends to make a good impression (requirement of practical rationality), and in some countries one needs to reject two times before accepting an invitation (rule of etiquette). 
Contrary to Hohfeld's definition (and to the third interpretation of Will Theory), $M 1$ thus explicates through concepts that are independent of the concept 'right', more basic than it and familiar from other and diverse contexts. Against M1, the triviality accusation hence seems unwarranted. ${ }^{31}$

\section{An Alternative Role for Interest: Claim 2 of Modal Theory}

According to $M 1$, to give a complete description of a right is to give a complete list of the stopping and forcing modals that correlate to this right. What place can this new theory allocate to the idea that rights protect interests? After all, Interest Theory does seem to capture an important aspect of rights: If, for instance, women in Saudi-Arabia demand the right to drive or if homosexuals demand the right to marry, then they certainly take the thing demanded to protect a justified interest.

Interest Theory refers to interests in order to describe what rights consist in, but on our new account this conception must be false. Within Modal Theory, we do not need to refer to $X$ 's interests if asked to specify what rights $X$ has or what it is for $X$ to have a right. We neither need interest to define the general term "right" nor to define any right $R$, say, "right to drive." $R$ will simply be defined through a set of stopping and forcing modals $m_{1}, \ldots, m_{n}$, and a right is what can be thus defined.

Now that we defined rights as sets of modals, however, a second question poses itself, viz.: What justifies the usage of such a set of modals? If, to return to our old example, I have a property right in a certain computer, then others must ask my permission to use it, can't use it without this permission, and so forth-but why are they under these constraints? After all, somebody else might need my computer more urgently then I do, or I might even do harmful things with it. If there is a place for interest in a theory of right, I shall argue, then interest will be what justifies the usage of the set of modals in which a given right consists. More precisely, I argue that interests justify at the level of the general right, not of its instantiation for a given individual.

This claim constitutes the second part of Modal Theory, and the idea for it is again inspired by Anscombe. ${ }^{32}$ A full-blown defense of this account would require a self-standing paper. But my aim in the current paper simply is to outline a new framework that avoids the standard difficulty of current theories of right.

We must distinguish two kinds of justifications of rights which, within our new framework, can be put as follows: First, there is the question of why a certain set of modals applies with respect to a certain individual. Second, there is the question of why this set of modals ever applies with respect to anyone. Take again the example of X's private property right in a certain computer: There is the question of why we should use-with respect to $X$ and for the case of this computer-the set of modals whose application would mean to grant $X$ a property right in this item. And then there 
is the question of why we should ever use this set of modals with respect to anyone for any item, that is, why we should ever grant people property rights. The first question asks whether the general right $R$ is instantiated in a given case. The second question asks what justifies $R$. One way to conceive of this difference is as the difference between justification within and of the 'private property game', i.e., justification within and of a certain social practice and its rules. ${ }^{33}$ I claim that we must appeal to interest in order to answer the second question. More precisely, I believe that rights are granted within practices, and the justification of such a practice as a whole, as well as of the rights granted within it, must ultimately appeal to interests. If there is a justification for why we should have the practice of private property, for example, and why this practice should assign the rights that our version of it does assign, then this justification will be that (our version of) this practice protects an interest that merits protection. Interest Theory seems to err in that it is not the instantiated but the general right, for which we need to draw on interest, and in that the protected interests must not necessarily be those of the right-holder. We can state this second part of Modal Theory as follows:

(M2) The usage of the set of modals that define right $R$ must be justified by appeal to an interest protected through this usage.

Notice three things about M2: (1) M2 does not imply that a right automatically arises as soon as there is an interest to be protected. All it says is that it is interest by which rights are justified. (2) M2 is compatible with a wide variety of ethical views because it is compatible with a wide variety of theories about the interests to be protected. (3) According to $M 2$, it is not the individual right $R_{i}$ which is justified by appeal to interest, but the general right $R$. In the library scenario, for instance, it would not be my individual right in this particular computer, but the general right in personal belongings that forms part of our current practice of private property, which must be justified by interest.

\section{Avoiding the "Wrong Kind of Reason" Objection}

The view that I suggest belongs to a category sometimes called "practice views" or "conventionalist views." 34 Practice views have been accused of giving the "wrong kinds of reasons" for actions and beliefs, so let me briefly explain why my particular view avoids this objection.

There actually are two such objections. First, Thomas Scanlon has argued that John Rawls mistakenly depicts any practice-internal duty as "a general obligation to the members of the group who have contributed to and benefit from the practice." 35 Rawls indeed justifies the duties that correspond to an individual right $R_{i}$ through a 
general duty of fairness that the holder of this duty has toward all other participants in the respective practice. ${ }^{36}$ An analogous move is made by rule-consequentialists: They, too, justify the duties that correspond to an individual right $R_{i}$ through a general duty to comply with the respective practice, only that this general duty is not justified by fairness but by the good which that practice furthers.

No such indirect justification of individual rights and duties is implied by the view I suggest here. Section 9 below lays this out in more detail. ${ }^{37}$ In a nutshell, I say: $\mathrm{R}_{i}$ must be justified through some empirical fact for which the rules of the practice assign $R$ to people (and hence assign the corresponding duties to others). For instance, the justification for why $I$ have a right in this computer could be that I bought this computer - an empirical fact for which the rules of our practice of private property assign me such a right and put all others under corresponding duties. The justification of the practice of private property itself has no role in justifying my individual right, not even an indirect role.

Second, inspired by Gregory Kavka's toxin puzzle, ${ }^{38}$ it has become a common place that considerations showing that it would be good to believe or intend something are not always the right kind of consideration to serve as reasons for believing or intending said thing. Suppose, you promised me a fortune if I believed that the moon is made of cheese: This would give me a (pragmatic) reason for intending to believe that the moon is made of cheese (or for attempting to get myself to believe it, e.g. by visiting a hypnotist), but it does not give me any (epistemic) reason to actually believe this. Similarly, even if $Y$ believed that there are good reasons to comply with the practice of private property and hence good pragmatic reasons to intend to believe that this computer is X's, this would not provide good epistemic reasons for $Y$ to believe that the computer indeed is X's.

Kavka's puzzle poses a problem for Rawls and for rule-consequentialists, but not for the view I suggest. On my account, Y's reason for believing that the computer is $X$ 's will be some empirical fact, such as that $X$ bought the computer, or that $X$ received the computer as a present, or that $X$ won the computer in a lottery, etc. It has nothing to do with legitimate interests that the practice of private property protects, not even indirectly.

All social practices, I believe, have this structure: There are two levels of justification-justification of the practice and justifications within the practice. What provides a good justification for beliefs or actions regarding the practice does not (at least not usually) provide a good justification for beliefs or actions within that practice and vice versa. Take the example of a social practice for which this is more obvious than it might be for private property: money. Most anthropologists think that human beings adopt money where there is need to trade with people whose credit history is unknown and with whom one has no social bonds. ${ }^{39}$ From the outside, money resembles a great social illusion: The currency itself often is of little material value; never- 
theless all those engaged in the practice highly value the currency. So a human community can have good reason to believe that they should introduce money. And once the practice is in place, every single member has good reason to believe that the respective paper pieces are valuable. This second good reason differs from the original good reason for adopting money: It consists in the fact that others, too, treat the paper pieces as valuable, e.g. by accepting them in exchange for desirable objects. Not only, however, do the two good reasons differ, but the good reason for beliefs about the paper pieces does not draw on the good reason for beliefs regarding the practice-not even indirectly. In fact, individual agents might hold no beliefs at all regarding the question of what money in general is for, and they would still have good reason to believe in the value of the pieces of paper. Similarly, $Y$ can have good reason to believe that, e.g., this is $X$ 's computer, or that he, $Y$, must not take the computer without $X$ 's permission, without holding any beliefs about the question of what private property in general is for.

\section{Interest Theory's Main Problem: The Possessor of a Right Might Not Be Its Beneficiary}

As mentioned in the introduction, the standard problem for Interest Theory is that it cannot allow that we possess rights which exclusively or mainly serve the interest of others. Much-discussed examples are the rights of legal guardians or the rights of office-holders. (Thus, a policeman's right to arrest someone does not serve this policeman's personal interest, but the interest of the political entity that employs him.) As for Will Theory, however, the set of counterexamples to Interest Theory is much larger than commonly discussed: Any justification of a right for subgroups through appeal to the general interest contradicts Interest Theory. Such appeals, however, are frequent in political discourse, and they seem to be correct as a form of argument (even if their respective content will sometimes be questionable).

Take the following example: In recent years, young people world-wide protested for the right to study without fees (in Chile, Germany and Hungary, for instance $)^{40}$ or at an affordable fee (for example in the UK, USA, Canada, Liberia, Nigeria and Taiwan). ${ }^{41}$ The right that they demand is free or affordable access to higher education. Their main justification for this demanded right can be rendered as follows: It is in the interest of all members of society that access to higher education be determined by talent, not money (and hence family background). For, first, to regulate access in this way furthers good research and national productivity, and those are aims in which all members of society have an instrumental interest. Second, to regulate access in this way is an important aspect of promoting social justice-given that today access to education determines access to all kinds of other resources-, and it is in the 
interest of all members of society to live in a just society. Whether you agree with these claims or not, the example illustrates two things:

1. Interest is usually brought in at the justificatory stage. It is not part of the specification of the right itself. "We (students) demand the right to $\varphi$ (study without or at affordable fees). The reason we give for this is that granting us this right would further this-or-that interest (national productivity, social justice)." In this, as in most other cases, the right itself can be specified without reference to interest, here as: "the right to study without/at affordable fees." Interests are mentioned in the attempt to justify the specified right: It is because of all those benefits that granting the right would be rational.

2. Often, it is not the right-holder's interest which serves to justify a right. True, in the above example it is also in the interest of all those to whom the right would be granted that they should have this right. (That is, all students and aspiring students profit from no or low fees.) But the given justification does not even mention these potential right-holders. It says that all members of society, most of whom have no intention to attend university and will hence never possess the right, will benefit. It is this general interest that justifies the right (if it does). This pattern of justification seems to be typical for many of the discussions about rights that we actually have: Very often, (claims for) rights for subgroups of a population are defended by appeal to the interest of the whole population. And Interest Theory has given us no reason to believe that this form of argument is generally invalid.

Notice that the first point, about specification, also holds where rights are denied. (The second point, about justification, does, too, of course - that is, it is not necessarily the right-holder's interest which serves to justify denial of the right to her-, but that seems obvious.) Consider the example of the recent large-scale protest in France against the right of homosexuals to adopt children. ${ }^{42}$ Protesters claimed that granting the discussed right to group $A$ (adult homosexuals) would negatively affect the mental health of another group $B$ (the children they adopt). Again, whether you agree with this claim or not (and many found it outrageous), the right under discussion can be specified without reference to anybody's interests — as "the right to adopt children", and the point to bring in interest is where one is pressed for a justification: This right must not be granted, because it would violate an important and legitimate interest.

M2 separates the question of the justification of rights from the question of their possession. It allows us to distinguish the bearer of a right from those whose interests this right generally protects, thereby allowing us to avoid Interest Theory's standard problem. As the above examples illustrate, however, it also has a further advantage: It captures the role that interest plays in actual public discussions about rights. 


\section{The Possession of Rights}

I defined rights through sets of deontic modal claims, and I argued that the general right, but not its individual instantiation, must be justified through interests. This leaves us with our third and last question, the question of the possession of rights.

As with the question of justification, the answer to the question of possession must start from a distinction between the general right and its individual instantiation (see p. 14). A property right in this item exists if (1) no one except __ can use it, (2) __ may destroy it, (3) all other must compensate __ if they destroy it, etc. The person who has this property right is the person whose name qualifies to fill in the blanks of these deontic modals. Who, in turn, qualifies for that will be a matter of empirical facts on the one hand and the rules of the practice to which the general right belongs on the other. According to the rules of our current property practice, for instance, you can come to qualify as the possessor of a property right through buying the item in question, through receiving it as a gift, through winning it as a prize etc. Whether you did this, is an empirical question. (Did you, in fact, draw the lottery ticket with the winning number, e.g.?) The possessor of a right hence is the person whose name can fill out the possessor blank (or: who can instantiate the possessor variable) that the deontic modals contain as which the right can be defined.

(M3) $X$ possesses right $R_{i}$ just in case " $X$ " can correctly be used to instantiate the modals that define $R$, where correct means: in accordance with the rules of the practice to which $R$ belongs, applied to the empirical facts.

Anscombe summarizes her own conception as follows: "I have located the generation of the concept of a right in a certain kind of use of a stopping modal [...]. We have here a very special use of the name of a person, or a very special way of relating something to a person, which explains (not is explained by) the general term 'right.' Something is N's to do, N's to receive (as: a message), N's to kill-as an ancient Roman would say about N's children: the patria potestas. The general term 'right' is constructed because, as it were, our language feels the need for it. As, for example, a general term 'relation' was invented." 43

\section{Conclusions}

I have outlined a new role for authority and interest in the theory of right - the key concepts of the two currently dominant theories, Will and Interest Theory. The resulting Modal Theory of Right comprises three central claims: 
(M1) Any right $\mathrm{R}$ can be defined through a set of stopping and forcing modals.

(M2) The usage of the set of modals that define right $\mathrm{R}$ must be justified by appeal to an interest protected through this usage.

$X$ possesses right Ri just in case " $X$ ” can correctly be used to instantiate the modals that define $R$, where correct means: in accordance with the rules of the practice to which $R$ belongs, applied to the empirical facts.

(1) I have argued that if we conceive of rights in this way, we can avoid the problems of Will and Interest Theory. (2) I hope to have shown that Will Theory's problems derive from a misconception of the connection between authority and rights, those of Interest Theory from a misconception of the connection between interests and rights. And instead of ad hoc patches for those problems, I have tried to provide a systematic solution. (3) Although I have not demonstrated that authority and interest need to be part of a correct theory of right, I have tried to endow the new alternative with some independent credibility: Modal Theory, I argued, analyzes rights through very basic and familiar concepts (p. 12); it accurately reflects actual public discourse about rights (Sect. 8), and it is compatible with a wide variety of ethical views (p. 14). Given that it puts very few constraints on the relevant kind of interest, it can be combined with any ethical theory that can accommodate rights and that allows for rights to be grounded in interests. This would include virtue ethics, for instance, certain forms of consequentialism and also many of the contemporary Kantian accounts, which stress the role of Glückseligkeit.

Modal Theory becomes available once we distinguish three questions: First, in what does a right consist? Second, what justifies rights? And, third, who possesses a certain right? On our alternative understanding, we need the concept 'authority' to answer the first question, while we need 'interest' to answer the second.

\section{Notes}

\footnotetext{
${ }^{1}$ See, e.g., Rowan Cruft, "Introduction," Ethics 123, no. 2 (2013): 196-98. Strictly speaking, the names "Will Theory" and "Interest Theory" denote families of theories. Given that I am only interested in the central idea uniting each family, I shall use the singular.

2 See, e.g., Hillel Steiner, "Directed Duties and Inalienable Rights," Ibid.: 231; his "Working Rights," in A Debate over Rights: Philosophical Enquiries, ed. Matthew H.
} 
Kramer, Nigel E. Simmonds and Hillel Steiner (Oxford; New York: Clarendon, 1998), 238; N. E. Simmonds, "Rights at the Cutting Edge," in Ibid., 214-15; or: Adina Preda, "Group Rights and Group Agency," Journal of Moral Pbilosopby 9, no. 2 (2012): 230. The locus classicus is H. L. A. Hart's "Legal Rights," in Essays on Bentham: Studies in Jurisprudence and Political Theory, ed. H. L. A. Hart (Oxford; New York: Clarendon, 1982), $182-83$.

${ }^{3}$ Immanuel Kant, Die Metaphysike der Sitten, in Kants Gesammelte Schriften Vol. 6, ed. by the Königlich Preußische Akademie der Wissenschaften, (Berlin: Reimer, 1909, $\left.{ }^{1} 1797\right)$, 230-32. H. L. A Hart gives a defense of these claims without presupposing the larger Kantian framework in: "Are There Any Natural Rights?”, Philosophical Review 64, no. 2 (1955).

${ }^{4}$ See especially the work of Alan Gewirth, such as Human Rights: Essays on Justification and Applications (Chicago: University of Chicago Press, 1982). James Griffin's On Human Rights (Oxford; New York: Oxford University Press, 2008), 29-51, also grounds human rights in action-theoretic considerations, but Griffin does not regard all denials of these rights as contradictory (Ibid., 4).

${ }^{5}$ See, e.g., Matthew H. Kramer, "Some Doubts About Alternatives to the Interest Theory of Rights," Etbics 123, no. 2 (2013): 246; his "Refining the Interest Theory of Right," American Journal of Jurisprudence 55 (2010): 32; Simon Căbulea May, "Moral Status and the Direction of Duties," Ethics 123, no. 1 (2012): 116, 25; Joseph Raz, "Human Rights without Foundations," University of Oxford Faculty of Law Legal Studies Research Paper Series 14 (2007): 235-36; and his influential The Morality of Freedom (Oxford; New York: Clarendon, 1986), 166. The original proposal is by David Lyons, "Rights, Claimants and Beneficiaries," American Pbilosophical Quarterly 6, no. 3 (1969): 173.

${ }^{6}$ See Lyons, Ibid., 173.

7 Most influential among these has been John Finnis, Natural Law and Natural Right (Oxford; New York: Clarendon 1980), see especially 198-225.

${ }^{8}$ This counterexample is by Raz himself, who tries to solve it through the idea of doubly-harmonious interests; see his "Rights and Individual Well-Being," in Ethics in the Public Domain: Essays in the Morality of Law and Politics, ed. Joseph Raz (Oxford; New York: Clarendon, 1994), 50.

${ }^{9}$ Leif Wenar, "Rights," in The Stanford Encyclopedia of Philosophy, ed. Edward N. Zalta. (2011, ${ }^{12005), ~ h t t p: / / p l a t o . s t a n f o r d . e d u / e n t r i e s / r i g h t s / . ~(S e e ~ s e c t i o n ~ 2.2 .2, ~ \$ 13 .) ~}$

${ }^{10}$ See Gopal Sreenivasan, "A Hybrid Theory of Claim Rights," Oxford Journal of Legal Studies 25, no. 3 (2005).

${ }^{11}$ See, e.g., Matthew H. Kramer and Hillel Steiner, "Theories of Rights: Is There a Third Way?," Ibid. 27, no. 2 (2007): 308-10.

${ }^{12}$ Kramer, "Some Doubts About Alternatives to the Interest Theory of Rights," 24647. 
${ }^{13}$ Kramer repeats this argument in various places, for example in his contribution to Keith E. Whittington, R. Daniel Kelemen and Gregory A. Caldeira, The Oxford Handbook of Law and Politics, Oxford Handbooks of Political Science (Oxford; New York: Oxford University Press, 2008), 417-18. There (see propositions I-1 and $W-1$ ), as well as in the above-quoted article (see propositions $I-2$ and $W$ ), he actually states Interest Theory in such a way that the negation of Will Theory is an independent und unconnected part of Interest Theory. Given that any theory, regardless of its content, could be made incompatible with Interest Theory through adding the negation of Interest Theory to it, this part of the discussion shall be ignored here.

${ }^{14}$ Kramer, "Some Doubts About Alternatives to the Interest Theory of Rights," 245.

${ }^{15}$ Wenar, "Rights," section 2.2.2, \$\$16-17.

${ }^{16}$ Wesley Newcomb Hohfeld, "Some Fundamental Legal Conceptions as Applied in Judicial Reasoning," Yale Law Journal 23 (1913): 9.

${ }^{17}$ See, e.g., Rowan Cruft, "Why Is It Disrespectful to Violate Rights?" Proceedings of the Aristotelian Society 113, no. 2 (2013): 201-24, and Simon Căbulea May, "Moral Status and the Direction of Duties."

${ }^{18}$ For a summary of counterarguments against the explication of rights through directed duties see Marcus Hedahl, "The Significance of a Duty's Direction: Claiming Priority rather than Prioritizing Claims," Journal of Ethics and Social Philosophy 7 (2013): 2.

${ }^{19}$ See William A. Edmundson, An Introduction to Rights, Cambrige Introductions to Philosophy and Law (Cambrige: Cambrige UP, 2004), 122-25. (Edmundson claims that the problem even occurs within the purely legal context, see 124).

${ }^{20}$ Hart, "Legal Rights," 182.

21 "The idea is that of one individual being given by the law exclusive control, more or less extensive, over another person's duty so that in the area of conduct covered by that duty the individual who has the right is a small scale sovereign to whom the duty is owed. The fullest measure of control comprises three // distinguishable elements: (i) the right holder may waive or extinguish the duty or leave it in existence; (ii) after breach or threatened breach of a duty be may leave it 'unenforced' or may 'enforce' it by suing for compensation or, in certain cases, for injunction or mandatory order to restrain the continued or further breach of duty; and (iii) he may waive or extinguish the obligation to pay compensation to which the breach gives rise." Ibid., 182-83. (Emphasis added.)

${ }^{22}$ E.g., Leif Wenar, “The Nature of Claim-Rights,” Ethics 123, no. 2 (2013): 202.

${ }^{23}$ Will Theorists sometimes react to this criticism by saying that they are prepared to bite the bullet of denying rights to the comatose and babies. This move, however, simply means to declare Will Theory the winner in this long-standing debate through claiming that the main objection levelled against Will Theory is insignificant or pales beside its advantages. 
${ }^{24}$ Even this modification would still exclude a type of right that I completely bracketed in this paper: animal rights.

25 'Recognizing, as we must, the very broad and indiscriminate use of the term, 'right,' what clue do we find, in ordinary legal discourse, toward limiting the word in question to a definite and appropriate meaning? That clue lies in the correlative 'duty,' for it is certain that even those who use the word and the conception 'right' in the broadest possible way are accustomed to thinking of 'duty' as the invariable correlative. [...] In other words, if $X$ has a right against $Y$ that he shall stay off the former's land, the correlative (and equivalent) is that $Y$ is under a duty toward $X$ to stay off the place." In: Hohfeld, "Some Fundamental Legal Conceptions as Applied in Judicial Reasoning," 9. (Emphasis added.)

${ }^{26}$ See particularly: Elizabeth Anscombe, "Rules, Rights and Promises," in The Collected Philosophical Papers of G. E. M. Anscombe, Vol. 3: Ethics, Religion and Politics (Oxford: Blackwell, 1981); but also her "On the Source of the Authority of the State," in Ibid., 138-46; and her "The Question of Linguistic Idealism," in The Collected Philosophical Papers of G. E. M. Anscombe, Vol. 1: From Parmenides to Wittgenstein (Oxford: Blackwell, 1981), 118-21.

${ }^{27}$ Roger Teichmann, The Philosophy of Elizabeth Anscombe. (Oxford: Oxford University Press), 79. Anscombe uses the adjective "permissive" to describe those modals in "The Question of Linguistic Idealism," 118. As Teichmann points out, "A permitting modal, such as 'may' can be defined as the negation of a stopping modal." This might explain the absence of a name for the third group

${ }^{28}$ It would not be an explication of 'property right' in general, because this category comprises a wide variety of rights. There are different types of property rights, and the way to differentiate them is precisely by differentiating the sets of deontic modals as which they can be explicated. Thus, the property right I have in my computer entails that I may set it on fire, which my property right in my house or my horse does not. For a discussion of types of property see: Jeremy Waldron, The Right to Private Property (Oxford: Clarendon, 1988), 26-61.

${ }^{29}$ There recently is much debate about "bipolar judgments" and whether those are reducible to "monadic judgments" - see, e.g., Michael Thompson, "What Is It to Wrong Someone? A Puzzle About Justice," in Reason and Value. Themes from the Moral Philosophy of Joseph Raz, ed. R. Jay Wallace, et al. (Oxford; New York: Clarendon, 2004), 335. Given that my above modal claims (such as "You can't take that!") address only one person, some readers might wonder whether Modal Theory entails such a reduction. The answer is that it does not. If you regard moral bipolar judgments as irreducible to monadic ones, you will think that all monadic formulations, like $X$ has a right to ..., have a logical counterpart (in this case $Y$ bas a duty to ...), and that although the individual judgment is monadic, its truth presupposes the truth of this counterpartjudgment, and you will hold that this does "the work of importing bipolarity into the equation" (Ibid., 349). 
${ }^{30}$ Hohfeld, "Some Fundamental Legal Conceptions as Applied in Judicial Reasoning," 9.

${ }^{31}$ There is a fourth reason why $M 1$ does not collapse into Hohfeld's analysis, viz. that it entails a strong metaphysical commitment about rights. It can be shown that if $M 1$ is true, then rights only exist where usage of the relevant class of modal expressions does, in other words, where there is a corresponding social practice. But such a demonstration requires a self-standing treatment. (Please see my "Do Rights Exist by Convention or by Nature?”, in Topoi 35, no. 1 (2016).)

${ }^{32}$ Particularly by "On Promising and Its Justice and whether It Need Be Respected in foro interno," in The Collected Philosophical Papers of G. E. M. Anscombe, Vol. 3: Ethics, Religion and Politics (Oxford: Blackwell, 1981).

${ }^{33}$ For this distinction, see John Rawls, "Two Concepts of Rules," Philosophical Review 64, no. 1 (1955).

${ }^{34}$ See, e.g., Allen Habib, "Promises." In The Stanford Encyclopedia of Philosophy, ed. Edward N. Zalta. (2014, ${ }^{1}$ 2008), http://plato.stanford.edu/entries/promises/ . (See section 5.3.)

35 Thomas Scanlon, "Promises and Practices," Philosophy and Public Affairs 19, no. 3 (1990): 221.

${ }^{36}$ See John Rawls, A Theory of Justice (Cambridge, Mass.: Belknap, 1999, $\left.{ }^{1} 1971\right)$ : sections 18 and 52 .

${ }^{37}$ Please see also my "Practice Views Revisited" [Manuscript].

${ }_{38}$ Gregory S. Kavka, "The Toxin Puzzle,” Analysis 43, no. 1 (1983): 36.

${ }^{39}$ For an overview, see David Graeber, Debt: The First 5,000 Years (Brooklyn, NY: Melville House 2011), ch. 2.

${ }^{40}$ See, e.g., Gideon Long, "Chile Student Protests Point to Deep Discontent," BBC News, Aug. 11th 2011; [unnamed], „Das Ende der Studiengebühren,“ Frankfurter Rundschau 2013; or: Krisztina Than, Marton Dunai and Michael Roddy, "Thousands of Hungarian Students Rally against Government,” Reuters US, Dec. 12th 2012.

${ }^{41}$ See, e.g., Sean Coughlan, "Thousands March in Student Protest over University Fees," BBC News, Nov. 9th 2011; Jeff Tylor, "Students on Hunger Strike to Protest Fee Hikes," Marketplace, May 2nd 2012; Peter Hallward, "Quebec's Student Protesters Give UK Activists a Lesson," The Guardian, US, June 1st 2012; Ishmael Tongai, "University Head Defends Fee Hike That Sparked Protests," University World News, Jan. 31st 2013; Abubakar Abdullahi Nasiru, "Ebonyi University Students Protest Increase in Fees," Premium Times, Feb. 5th 2013; or: Lok-sin Loa, "Students Protest Change in University Fee Regulations,” Taipei Times, Feb. 22nd 2013.

${ }^{42}$ See, e.g., Samuel Laurent, "Adoption et mariage homosexuel: Les faits pour comprendre, » Le Monde, Jan. 30th 2013.

${ }^{43}$ Anscombe, "On the Source of the Authority of the State," 142. 